\title{
Oral estramustine phosphate and oral etoposide for the treatment of hormone-refractory prostate cancer
}

\section{$\operatorname{AUTHOR}(S):$}

Numata, Kousaku; Miura, Noriyoshi; Azuma, Koji; Karashima, Takashi; Kasahara, Kotaro; Nakatsuzi, Hironori; Hashine, Katsuyoshi; Sumiyoshi, Yoshiteru

\section{CITATION:}

Numata, Kousaku ...[et al]. Oral estramustine phosphate and oral etoposide for the treatment of hormone-refractory prostate cancer. 泌尿器科紀要 2007, 53(2): 99-104

\section{ISSUE DATE:}

2007-02

URL:

http://hdl.handle.net/2433/71352

RIGHT: 


\title{
ORAL ESTRAMUSTINE PHOSPHATE AND ORAL ETOPOSIDE FOR THE TREATMENT OF HORMONE-REFRACTORY PROSTATE GANGER
}

\author{
Kousaku Numata, Noriyoshi Miura, Koji Azuma, Takashi Karashima, \\ Kotaro Kasahara, Hironori Nakatsuzi, Katsuyoshi Hashine and Yoshiteru Sumiyoshi \\ The Department of Urology, Shikoku Cancer Center
}

A total of 42 patients with hormone-refractory prostate cancer received E-E therapy. Oral estramustine phosphate (EMP) was administered twice daily for a total daily dose of $560 \mathrm{mg}$ every day and oral etoposide (E-E therapy, $50 \mathrm{mg} /$ body/day) was given on days 1-21 and stopped on days 22-35. Treatment was continued until the disease progression was confirmed radiographically or PSA had increased from base line of at least $25 \%$. The median follow-up period after E-E therapy was 77.4 months (range : 12.5 to 122.3 ). Nineteen patients (43\%) achieved a PSA decrease of $50 \%$ or greater. The median survival time of the patients who had a decrease of $50 \%$ or greater in the PSA value (PSA responder) was 29.3 months and the patients who did not (PSA non-responder) was 14.1 months $(p=0.01)$. There were no significant differences between PSA responders and non-responders when taking into account variables. Excluding those patients with only PSA elevation, the survival time was 14.9 months with no significant difference between PSA responders and non-responders. The toxicities (grade 3 or more) were identified as anemia, leukocytopenia thrombocytopenia, cardiovascular events, and gastrointestinal and hepatic disorders, which occurred in $0,5,2,2,14$, and $2 \%$ of the patients, respectively.

E-E therapy was considered to be an active oral regimen and well-tolerated for outpatients with hormone-refractory prostate cancer in Japanese patients.

(Hinyokika Kiyo 53 : 99-104, 2007)

Key words : Hormone-refractory prostate cancer, Estramustine phosphate, Etoposide

\section{INTRODUCTION}

The widespread approach of measuring prostate specific antigen (PSA) has increased the detection of prostate cancer. It is estimated that 232,090 men in the United States are diagnosed with prostate cancer and 30,350 deaths occur in 2005. It is the second largest cause of cancer death in males ${ }^{1)}$. In Japan, it is estimated that annually 15,814 men are diagnosed with prostate cancer and that 7,514 deaths occur in 2004. It is the eighth largest cause of cancer death in males ${ }^{2)}$. The levels of mortality and morbidity attributed to prostate cancer are increasing in Japan. For patients with metastatic lesions, androgen deprivation therapy (ADT) is the primary therapeutic approach for advanced prostate cancer. The initial response rate to ADT is 80 to $90 \%$, but nearly all men develop progressive disease after 18 to 24 months. The median survival of men with hormone-refractory prostate cancer (HRPG) is approximately 12 months ${ }^{3)}$. Once the disease becomes hormone-refractory it is very difficult to cure using other treatment modalities.

Estramustine phosphate (EMP) is a stable conjugate of estradiol and nitrogen mustard that possesses antimitotic properties and causes disruption of microtubule organization. EMP is a representative agent for patients with HRPC in Japan and its response rate as a single agent was reported as $30 \%$ in a phase II study ${ }^{4,5)}$.
Several other clinical trials were reported using a combination of EMP and various cytotoxic agents ${ }^{6-8)}$.

Pienta et al. previously reported on efficacy using a combination of EMP and oral etoposide (VP-16) for patients with $\mathrm{HRPC}^{9)}$. In the study, the response rate for measurable disease was $50 \%$ and PSA response (PSA decrease by at least $50 \%$ ) rate was $50 \%$.

We previously reported on a short follow-up result using a combination of EMP and oral VP-16 (E-E therapy) in 20 Japanese patients ${ }^{10}$. Ten of the 20 patients showed a decrease of $50 \%$ or greater in the PSA value from initially elevated PSA levels after therapy. The median progression-free duration and 2-year causespecific survival rate of these 10 patients were 208 days (range 71-693 days) and 67.5\%, respectively. The purpose of our current study is to evaluate the longitudinal results of E-E therapy in Japanese patients.

\section{METHODS}

Between February 1995 and April 2004, 42 patients with HRPC were enrolled in this study at the Shikoku Cancer Center. All patients were histologically confirmed as having prostatic adenocarcinoma. To be eligible for this study, three consecutive occurrences of PSA elevation during hormone deprivation therapy and anti-androgen withdrawal therapy were confirmed for all patients. Table 1 shows patient characteristics. The median age at E-E therapy was 71 (range: 56 to 85) 
Table 1. Patient characteristics

\begin{tabular}{|c|c|c|}
\hline No. of cases (n) & \multicolumn{2}{|l|}{42} \\
\hline Age (yrs) & \multicolumn{2}{|l|}{$71(56-85)$} \\
\hline Initial PSA (ng/ml) & \multicolumn{2}{|l|}{$139.5(3.1-5,440)$} \\
\hline \multirow[t]{4}{*}{ Initial stage $(\mathrm{n})$} & B & 2 \\
\hline & G & 8 \\
\hline & D1 & 7 \\
\hline & D2 & 25 \\
\hline Pretreatment PSA (ng/ml) & $10.9(0.2-1,110)$ & \\
\hline \multirow[t]{3}{*}{ Initial therapy (n) } & Prostatectomy & \\
\hline & Radiation & 2 \\
\hline & Hormone & 31 \\
\hline PSADT (month) & $2.0(0.4-15.8)$ & \\
\hline \multicolumn{3}{|c|}{ (From hormone-relapse to pretreatment) } \\
\hline Duration (month) & $18.1(3.3-66.3)$ & \\
\hline \multicolumn{3}{|c|}{ (From initial therapy to pretreatment) } \\
\hline \multirow[t]{2}{*}{ Pretreatment measurable disease (n) } & Lymph node & \\
\hline & liver & 2 \\
\hline Osseous disease (n) & 25 & \\
\hline PSA elevation only (n) & 14 & \\
\hline Prior chemotherapy $(\mathrm{n})$ & 13 & \\
\hline
\end{tabular}

years. The median pretreatment PSA was 10.9 (range : 0.2 to 1,110$) \mathrm{ng} / \mathrm{ml}$. Eight patients underwent surgical or medical castration only and 34 patients underwent castration in combination with androgen blockade (CAB). Thirteen patients received cytotoxic chemotherapy which was mainly ifosfamide. Two patients received docetaxel-prednisolone after becoming E-E refractory. Measurable soft tissue disease confirmed 7 lesions including 5 nodal and 2 liver metastases. Twenty-five patients had osseous disease. Fourteen patients had only PSA elevation. The IMx PSA assay system (Abbott, Japan) was used to determine serum PSA values until 1997 and then Architect assay system (Abbott, Japan) were used. PSA measurements were at least 4 weeks apart. Informed consent was obtained from all patients before entry into this study.

Treatment schedule
The treatment was administered in an outpatient setting. EMP was administered twice daily for a total daily dose of $560 \mathrm{mg}$. Oral etoposide $(50 \mathrm{mg} /$ body/ day) was given on days 1-21 and stopped on days 22-35. An $\mathrm{H}_{2}$-blocker was administered prophylactically to alleviate nausea/vomiting. The treatment cycle was repeated and continued until evidence of disease progression (PD) or unacceptable toxicities were observed.

Response and toxicity criteria

The PSA response was defined as a reduction from baseline by at least $50 \%$ that was maintained for 4 weeks. Patient with this response were defined as PSA responders. PSA non-responders were defined as not achieving the response criterion. The PSA progression was defined as an increase from baseline of at least $25 \%$. The measurable soft tissue disease was evaluated according to the guideline contained in the "General Rules for Clinical and Pathological Studies on Prostate Cancer (3rd edition)" ${ }^{11)}$. Toxicities were graded using the "National Cancer Institute-Common toxicity criteria (NCI-CTG) version 2".

Statistical methods

The chi-squared test was used to compare the characteristics between PSA responders and non-responders. A P-value $<0.05$ was considered significant. KaplanMeier methods were used for estimation of the survival curve. Survival between PSA responders and nonresponders was compared using the log-rank test. A Pvalue $<0.05$ was considered significant. The PSA doubling time (PSADT) was calculated from the slope (0.693 divided by the slope) of the regression line between hormone-relapse and pretreatment.

\section{RESULTS}

The median follow-up time was 77.4 (range: 12.5 to 122.3) months. The median treatment course was 6 (range : 1 to 30) courses. During follow-up, 6 patients were alive and 36 patients died. Of the 36 dead patients, 33 died of prostate cancer. The other three patients died of malignant lymphoma, pneumonia and

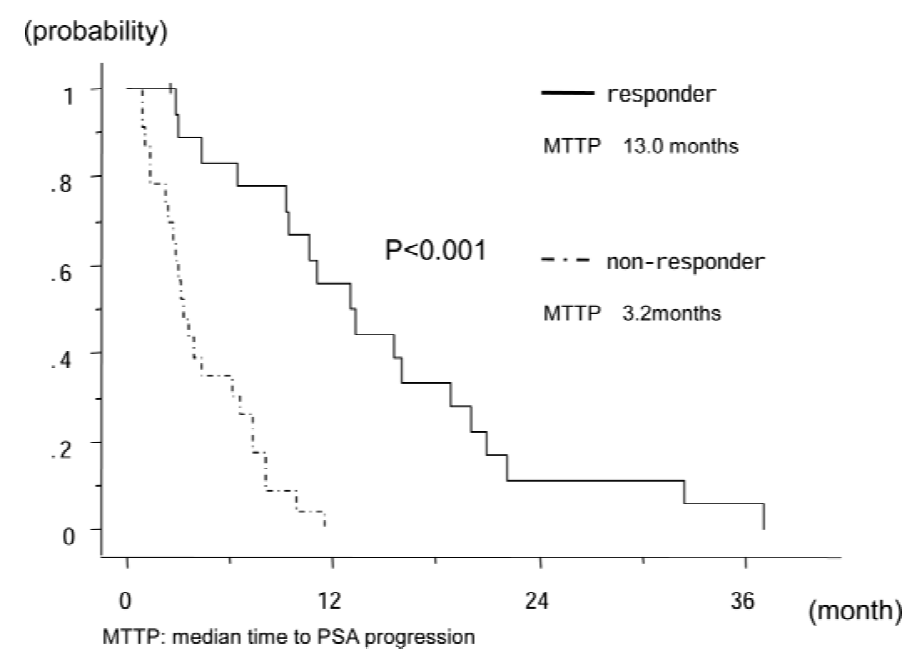

Fig. 1. The time to PSA progression based on response. 


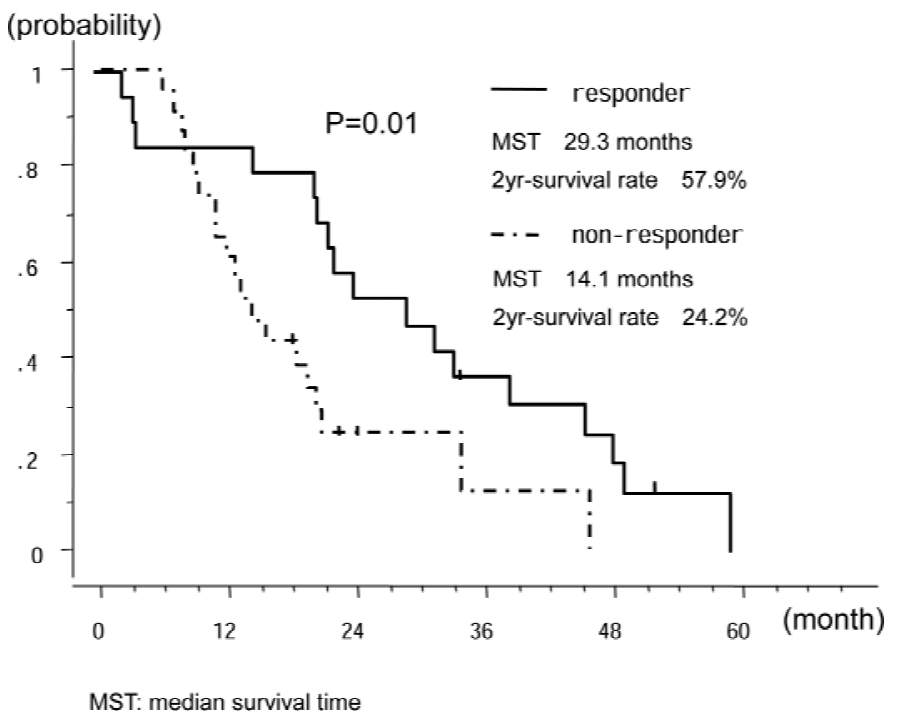

Fig. 2. The overall survival curve based on response.

unknown causes, which were not associated with prostate cancer or its treatment. Of the 42 patients, 19 patients $(43 \%)$ were PSA responders. Fig. 1 shows the time to PSA progression based on PSA response. The median time to PSA progression was 13.0 months in responders, while 3.2 months in responders. The difference was significant $(\mathrm{p}<0.001)$. In the measurable soft tissue disease, 2 patients had complete remission $(\mathrm{CR})$ and 3 patients had no change $(\mathrm{NG})$ for the 5 lymph node diseases. Of the 2 liver disease patients, 1 patient had $\mathrm{NG}$ and 1 had PD. Variables were compared between 19 responders and 23 nonresponders and included age at treatment, PSA level at diagnosis, pretreatment PSA level, interval from initial therapy to E-E therapy, PSADT, clinical stage at diagnosis and whether prior chemotherapy was administered or not. There were no significant differences in the variables.

The 2-year overall survival rate was $39.5 \%$ and the median survival time was 20.5 months for all patients. Fig. 2 shows the overall survival according to PSA response. The 2-year survival rate of PSA responders and non-responders was 57.9 and $24.2 \%$ and the median survival time was 29.3 and 14.1 months, respectively. The difference was significant $(\mathrm{p}=0.01)$.

Table 2. Toxicities

\begin{tabular}{|c|c|c|c|c|c|c|}
\hline NGI-CTG grade & 0 & 1 & 2 & 3 & 4 & $\mathrm{G} 3 / 4$ \\
\hline \multicolumn{7}{|l|}{ Blood } \\
\hline Hemoglobin & 25 & 10 & 7 & 0 & 0 & 0 \\
\hline Leukocytes & 39 & 0 & 1 & 1 & 1 & $5 \%$ \\
\hline Platelets & 40 & 1 & 0 & 1 & 0 & $2 \%$ \\
\hline Cardiovascular & 34 & 5 & 2 & 1 & 0 & $2 \%$ \\
\hline Gynecomastia & 25 & 17 & 0 & 0 & - & 0 \\
\hline $\begin{array}{l}\text { Gastorointestinal (nausea/vom- } \\
\text { iting) }\end{array}$ & 14 & 13 & 9 & 6 & 0 & $14 \%$ \\
\hline Hepatic disorder & 40 & 1 & 0 & 1 & 0 & $2 \%$ \\
\hline
\end{tabular}

Hematological and non-hematological toxicities are shown in Table 2. The toxicities (grade 3 or more) were evaluated as anemia, leukocytopenia, thrombocytopenia, cardiovascular events, and gastrointestinal and hepatic disorders, which occurred in 0, 5, 2, 2, 14, and $2 \%$ of patients, respectively. Five patients stopped treatment due to toxicities. Of the 5 patients, 4 patients had severe gastrointestinal toxicity and 1 patient had cardiovascular toxicity (deep venous thrombosis).

\section{DISCUSSION}

Estramustine phosphate (EMP), a nor-nitrogen mustard carbamate derivative of estradiol-17 $\beta$-phosphate, binds to microtubule organization in vitro ${ }^{12)}$ and has been used as a chemohormonal agent for patients with hormone-refractory prostate cancer. Iversen et al. reported that, in a randomized double-blind multicenter trial in which patients with HRPG were treated with either EMP or a placebo, EMP was not superior to the placebo in terms of subjective progression or overall survival $^{13)}$. Etoposide is a podophyllotoxin derivative that is known to inhibit topoisomerase II at the nuclear matrix level ${ }^{14)}$. Hussan et al. reported that alone, it demonstrates little activity in the treatment of $\mathrm{HRPC}^{15)}$.

In preclinical studies using both human-derived cells and Dunning rat prostate adenocarcinoma cells, Pienta et al. demonstrated significant growth inhibition by these two agents in combination despite poor activity as single agents $^{16)}$. In 1994, Pienta et al. initially reported on EE therapy ${ }^{9)}$. EMP at $15 \mathrm{mg} / \mathrm{kg} /$ day and VP-16 at 50 $\mathrm{mg} / \mathrm{m}^{2} /$ day were administered to 42 patients orally in divided doses for 21 of 28 days. This study showed a $50 \%$ PSA decrease in $54 \%$ of patients. This regimen had a $50 \%$ response rate in 18 patients with soft tissue disease. Toxicities, however, were significant : $31 \%$ of patients had significant nausea from EMP and 10\% quit the study within 2 weeks of registration secondary to grade 3 nausea and vomiting. The median survival time 
was 44 weeks. Then, in a 1997 report, they changed the EMP dose ${ }^{17)}$. EMP $10 \mathrm{mg} / \mathrm{kg} /$ day and VP-16 50 $\mathrm{mg} / \mathrm{m}^{2} /$ day were administered to 62 patients orally in divided doses for 21 of 28 days. This study had a $50 \%$ PSA decrease in $39 \%$ of patients. This regimen had a $53 \%$ response rate in 15 patients with soft tissue disease. Toxicities decreased slightly and only $5 \%$ quit the study within 4 weeks of registration secondary to grade 3 nausea and vomiting. The median survival time was 56 weeks.

Dimopoulos et al. reported on a 56-patient series of EE therapy for $\mathrm{HRPC}^{18)}$. EMP $140 \mathrm{mg}$ three times a day and VP-16 $50 \mathrm{mg} / \mathrm{m}^{2} /$ day were administered for 21 of 28 days. Fifty-eight percent had PSA response and $45 \%$ of 33 patients with measurable soft tissue disease had an objective response. Twenty-two percent had grade 3 or 4 neutropenia and $11 \%$ had grade 3 or 4 thrombocytopenia. Grade 3 or 4 nausea/vomiting occurred in $8 \%$. Grade 1 or 2 edema occurred in $40 \%$ of patients. The median survival time was 13 months. These results (efficacy and toxicities) were similar to Pienta's results.

Our results showed that the PSA response rate was $43 \%$ and the response rate in the measurable soft tissue disease was 29\%. Although our regimen was a little different from other reports, the efficacy of E-E therapy was almost equal in Japanese patients to that seen in other races. In hematological toxicities, leukocytopenia occurred in only 3 patients $(7 \%)$ and thrombocytopenia occurred in only 2 patients $(5 \%)$. In non-hematological toxicities, nausea/vomiting occurred in $28 \mathrm{pa}-$ tients $(67 \%)$ and 6 patients had grade 3. Cardiovascular events occurred in 8 patients $(19 \%)$ and 1 patient had deep venous thrombosis requiring treatment with warfarin. Hematological toxicities were low compared to other reports. The reason was a low VP-16 dose. In our study, the VP-16 dose was $50 \mathrm{mg} /$ body/ day and the other study it was $50 \mathrm{mg} / \mathrm{m}^{2} /$ day. Although our regimen involved the administration of
EMP $560 \mathrm{mg}$ every day, the patients were administered a prophylactic $\mathrm{H}_{2}$-blocker and with the exception of 4 patients, all others were able to continue E-E therapy. The median survival time was 20.5 months and in responders 29.3 months. The survival time was very long compared to other reports. The reason was that our study included 14 cases with only PSA elevation. In other reports, all patients had osseous or measurable soft tissue disease ${ }^{9,17,18)}$. Excluding patients with only PSA elevation, the survival time was 14.9 months and there was no significant difference between responders and non-responders (Fig. 3).

Chemotherapy for HRPC was previously considered ineffective for improving survival time. The median survival time did not exceed 12 months. However, newer regimens, particularly those that include docetaxel are associated with higher rates both of objective and PSA response and improved quality of life (QOL). It is important to note that the median survival time approaches 2 years ${ }^{19,20)}$. Docetaxel binds to tubulin subunits and inhibits the disassembly of microtubules, which normally occurs during cell cycle progression, inactivating the antiapoptotic protein bcl-2 by phosphorylation and promoting apoptosis ${ }^{21)}$. The PSA response rate was $35-50 \%$ and the response rate in measurable soft tissue disease was $12-17 \%{ }^{19,20)}$. Severe toxicities were rare but neutropenia did occur. Grade 3 or 4 neutropenia occurred in $16.1-33 \%$ of patients ${ }^{19,29)}$. This regimen was approved by the Food and Drug Administration (FDA) and may become widely used as a first selection for HRPC in Japan.

In conclusion, the effectiveness of E-E therapy in Japanese patients was similar to that seen in other races in terms of tumor response. Toxicity was tolerable. Gastrointestinal symptoms were the most important complications and controlled using an $\mathrm{H}_{2}$-blocker. In the future, docetaxel will become the main treatment for HRPG. We recommend E-E therapy as a second-line chemotherapy or as a first-line chemotherapy for the

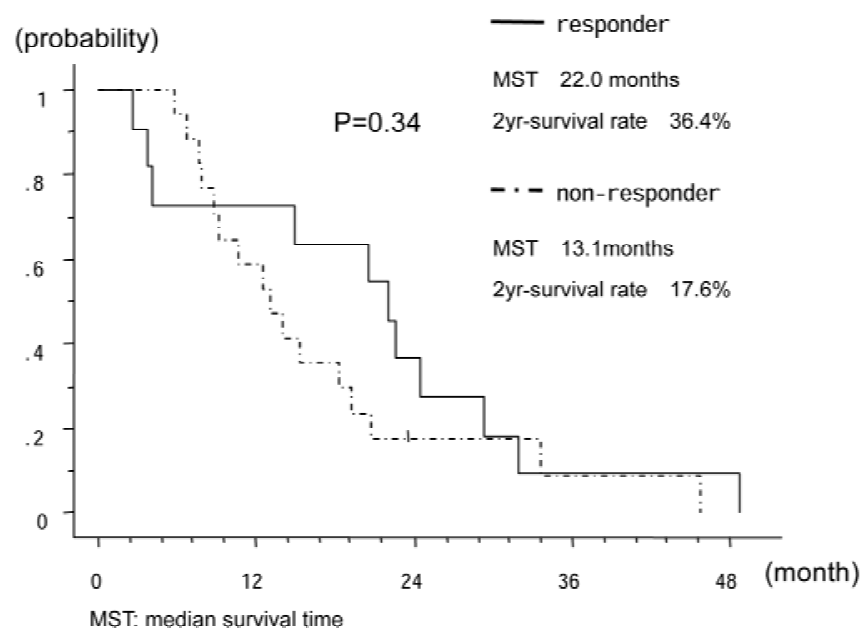

Fig. 3. The overall survival curve based on response without the patients with only PSA elevation. 
docetaxel-intolerant patients.

\section{REFERENCES}

1) American Cancer Society: Cancer Facts and Figures 2005. Atlanta, Ga: American Cancer Society, 2005

2) Cancer mortality and morbidity statistics-Japan and the world 2004. Japan Cancer Association

3) Smaletz O, Scher HI, Small EJ, et al. : Nomogram for overall survival of patients with progressive metastatic prostate cancer after castration. J Clin Oncol 20 : 3972-3982, 2002

4) Jonsson G, Hogberg B and Nilsson T : Treatment of advanced prostatic carcinoma with estramustine phosphate (Estracyt). Scand J Urol Nephrol 11 : 231-238, 1977

5) Benson RG, Wear JB and Gill GM : Treatment of stage $\mathrm{D}$ hormone-resistant carcinoma of the prostate with estramustine phosphate. J Urol 121: 452454, 1979

6) Smith MR, Kaufman D, Oh W, et al. : Vinorelbine and estramustine in androgen-independent metastatic prostate cancer. Cancer 89: 1824-1828, 2000

7) Seidman AD, Scher HI, Petrylak D, et al.: Estramustine and vinblastine: use of prostate specific antigen as a clinical trial end point for hormone refractory prostatic cancer. J Urol 147 : 931-934, 1992

8) Hudes GR, Nathan F, Khater G, et al. : Phase II trial of 96-hour paclitaxel plus oral estramustine phosphate in metastatic hormone-refractory prostate cancer. J Clin Oncol 15 : 3156-3163, 1997

9) Pienta KJ, Redman B, Hussan M, et al. : Phase II evaluation of oral estramustine and oral etoposide in hormone-refractory adenocarcinoma of the prostate. J Clin Oncol 12 : 2005-2012, 1994

10) Sumiyoshi $Y$, Hashine K, Nakatsuzi H, et al. : Oral estramustine phosphate and oral etoposide for the treatment of hormone-refractory prostate cancer. Int J Urol 7 : 243-247, 2000

11) General Rules for Clinical and Pathological Studies on Prostate Cancer, $3^{\text {rd }}$ ed. Japanese Urological Association, Japanese Society of Pathology 2001
12) Stearns ME, Wang M, Tew KD, et al.: Estramustine binds a MAP-1-like protein to inhibit microtubule assembly in vitro and disrupt microtubule organization in DU. J Gell Biol 107 : 26472656, 1988

13) Iversen P, Rosmussen F, Amussen C, et al. : Eatramustine phosphate versus placebo as second line treatment after orchiectomy in patients with metastatic prostate cancer: DAPROGA Study 9002. J Urol 157 : 929-934, 1997

14) Nelson WG, Liu LF and Coffey DS : Newly replicated DNA is associated with DNA topoisomerase II in cultures rat prostatic adenocarcinoma cells. Nature 322 : 187-189, 1986

15) Hussen MH, Pienta KJ, Redman BG, et al. : Oral Etoposide in the treatment of hormone-refractory prostate cancer. Cancer 74: 100-103, 1994

16) Pienta KJ and Lehr JE: Inhibition of prostate cancer growth by estramustine and etoposide: evidence for interaction at the nuclear matrix. J Urol 149 : 1622-1625, 1993

17) Pienta KJ, Redman BG, Bandekar R, et al. : A phase II trial of oral estramustine and oral etoposide in hormone refractory prostate cancer. Urology 50 : 401-407, 1997

18) Dimopoulos MA, Panopoulos G, Bamia C, et al. : Oral estramustine and oral etoposide for hormonerefractory prostate cancer. Urology 50 : 754-758, 1997

19) Tannock IF, de Wit R, Berry WR, et al. : Docetaxel plus prednisone or mitoxantrone plus prednisone for advanced prostate cancer. New Engl J Med 35 : 1502-1512, 2004

20) Petrylak DP, Tangen CM, Hussain MH, et al. : Docetaxel and estramustine compared with mitoxantrone and prednisone for advanced refractory prostate cancer. New Engl J Med 35 : 1513-1520, 2004

21) Ringle I and Horwitz SB : Studies with RP 56976 (taxotere): a semisynthetic analogue of taxol. J Natl Cancer Inst 83 : 288-291, 1991

$$
\left(\begin{array}{ll}
\text { Received on April } 14,2006 \\
\text { Accepted on October } 13,2006
\end{array}\right)
$$




\section{和文抄録}

ホルモン抵抗性前立腺癌に対するリン酸エストラムスチン，エトポシド療法

沼田 幸作，三浦 徳宣，東 浩司，辛島 尚

笠原高太郎, 中逵 弘能, 橋根 勝義, 住吉 義光

四国がんセンター泌尿器科

【目的】日本人における再燃前立腺癌に対する経ロリ ン酸エストラムスチン (EMP)，エトポシド (VP-16) 併用療法 (EE 療法) の効果および副作用について検 討した。

【方法】1995年以降, $\mathrm{EE}$ 療法が施行された再燃前立 腺癌患者42例が対象. EMP : $560 \mathrm{mg}$ を連日投与, VP16：50 mg を21日投与し14日休薬を 1 サイクルとし た。PSA が50\%以上低下したものを responder とし， 治療は画像上の増覀または PSA が基準值より $25 \%$ を 認めるまで継続した。

【結果】観察期間は77.4力月. 19例が responder で
あった. 42 例の生存中央值は20.5 月西あり responder では29.3カ月, non-responder で14.1カ月 $(\mathrm{p}$ =0.008）であった．群間で response に寄与する因子 は存在しなかった. Grade 3 以上の副作用は白血球減 少 $(5 \%)$ が 2 例, 血小板減少 $(2 \%)$ が 1 例, 悪心 が 6 例 $(14 \%)$, 肝機能障害が 1 例 $(2 \%)$, 深部静脈 血栓症（2）が 1 例に認めた。

【結語】 $\mathrm{EE}$ 療法は抗腫瘍効果もあり, 副作用も容認 でき日本人にも施行可能であった。

（泌尿紀要 53 : 99-104，2007） 